\title{
Effect of antimicrobial agents on the Euglena method of serum vitamin $B_{12}$ assay ${ }^{1}$
}

\author{
J. T. LIE, ${ }^{2}$ BERTA UNGAR, AND D. C. COWLING \\ From the Department of Clinical Pathology, Royal Melbourne Hospital, Victoria, Australia
}

SYNOPSIS Antimicrobial agents in the serum may affect the results of the Euglena method of serum vitamin $B_{12}$ assay. Sulphonamides suppress the growth of Euglena in concentrations attainable in the serum during treatment; streptomycin, chlortetracycline, erythromycin, kanamycin, ander nitrofurantoin bleach Euglena but only when present in concentrations far exceeding the normal peak therapeutic blood levels. False low results of serum vitamin $B_{12}$ assay due to inhibitory and/or bleaching substances in the serum can be readily detected by microscopy of the assay cultures and Euglena cell counts.

Microbiological assay with Euglena gracilis is a specific and sensitive method of determining serum vitamin $B_{12}$ levels, provided constant and optimal assay conditions are observed (Anderson, 1964). On the basis that sulphonamides, when present in a patient's serum in concentrations attainable during treatment, suppress the growth of Euglena (Lear, Harris, Castle, and Fleming, 1954), Hutner, Bach, and Ross (1956) suggested that the addition of para-aminobenzoic acid to the serum should be included in the assay procedure to

${ }^{1}$ Requests for reprints to Dr Berta Ungar. Dept of Clinical Pathology, Royal Melbourne Hospital, Victoria 3050, Australia.

2Present address: Mayo Graduate School of Medicine. University of Minnesota, Rochester, Minnesota 55901, USA.

Received for publication 31 December 1968. overcome the inhibitory effect of sulphonamides. $\stackrel{\mathbb{T}}{=}$ Other workers have demonstrated that certain anti $\overrightarrow{0}$ biotics also affect the growth of Euglena (Robbins, Hervey, and Stebbins, 1953; Zahalsky, Hutner, Keane, and Burger, 1962; McCalla, 1962). We report here our investigation of the effect of a number of currently used antimicrobial agents on the Euglena method of serum vitamin $B_{12}$ assay.

\section{MATERIALS AND METHODS}

The concentration of vitamin $\mathrm{B}_{12}$ in the standard serum was assayed by the method described by Anderson (1964): using Euglena gracilis strain z. Two dilutions of the serum, 1 in 40 and 1 in 80, were used for each deter:-

TABLE I

EFFECT OF ANTIMICROBIAL AGENTS IN NORMAL PEAK THERAPEUTIC BLOOD LEVELS ON THE EUGLENA METHOD OF SERUM VITAMIN $B_{12}$ ASSAY $^{1}$

\begin{tabular}{|c|c|c|c|c|}
\hline \multirow[b]{2}{*}{ Drug Added to Serum } & & \multirow[b]{2}{*}{ Colour of Euglena } & \multirow[b]{2}{*}{$\begin{array}{l}\text { Mean Vitamin } B_{12} \\
(p g / m l)\end{array}$} \\
\hline & $\begin{array}{l}\text { Concentration } \\
(\mu \mathrm{g} / \mathrm{ml})\end{array}$ & $\begin{array}{l}\text { Mean Cell Count on } \\
\text { Day } 7\left(10^{5} / m l\right)^{2}\end{array}$ & & \\
\hline $\begin{array}{l}\text { None } \\
\text { Sulphonamides } \\
\text { Benzylpenicillin } \\
\text { Streptomycin } \\
\text { Chlortetracycline } \\
\text { Erythromycin } \\
\text { Chloramphenicol } \\
\text { Methicillin } \\
\text { Ampicillin } \\
\text { Cephaloridine } \\
\text { Colistimethate } \\
\text { Kanamycin } \\
\text { Gentamicin } \\
\text { Nitrofurantoin }\end{array}$ & $\begin{array}{l}0 \\
100 \\
10 \text { (unit/ml) } \\
50 \\
25 \\
50 \\
50 \\
25 \\
2 \\
25 \\
5 \\
25 \\
2 \\
2\end{array}$ & $\begin{array}{l}30 \\
2 \cdot 5 \\
31 \\
30 \\
30 \\
31 \\
31 \\
32 \\
31 \\
30 \\
31 \\
29 \\
30 \\
29\end{array}$ & $\begin{array}{l}\text { Green } \\
\text { Green } \\
\text { Green } \\
\text { Green } \\
\text { Green } \\
\text { Green } \\
\text { Green } \\
\text { Green } \\
\text { Green } \\
\text { Green } \\
\text { Green } \\
\text { Green } \\
\text { Green } \\
\text { Green }\end{array}$ & $\begin{array}{r}550 \\
<20 \\
564 \\
470 \\
498 \\
502 \\
546 \\
638 \\
588 \\
516 \\
602 \\
484 \\
574 \\
472 \\
\end{array}$ \\
\hline
\end{tabular}


mination. The size of the Euglena inoculum was $0.2 \times$ $10^{5}$ cells per millilitre. The antimicrobial agents were added to the standard serum in various concentrations, including those likely to be found in the human body during treatment with these drugs. Para-aminobenzoic acid was added to the serum in a concentration of 1.25 $\mu \mathrm{g} / \mathrm{ml}$. In addition to the usual colorimetric measurement of the assay cultures to determine the serum vitamin $B_{12}$ levels, the growth of Euglena was also assessed at regular intervals by light microscopy, with particular attention to the size, colour, and motility of the flagellates. Euglena cell counts were made in a haemocytometer.

RESULTS

The mean value of vitamin $B_{12}$ in the standard serum from 30 determinations was $550 \mathrm{pg} / \mathrm{ml}$, with a range of 468 to $634 \mathrm{pg} / \mathrm{ml}$. The average Euglena cell count at the time of harvest (day 7) was $30 \times 10^{5}$ cells $/ \mathrm{ml}$. All the flagellates grown in the drug-free standard serum and in sera containing low concentrations of vitamin $B_{12}$ (less than $20 \mathrm{pg} / \mathrm{ml}$ ) were plump and green; over $90 \%$ of the population were motile.

THE EFFECT OF ANTIMICROBIAL AGENTS IN CONCENTRATIONS ATTAINABLE IN THE SERUM DURING TREATMENT With the exception of sulphonamides, all drugs tested had no significant effect on the growth of Euglena, as judged by the Euglena cell counts, the appearance of the flagellates, and the serum vitamin $\mathrm{B}_{12}$ measurements (Table $\mathrm{I}$ ).

Eight short- and long-acting sulphonamides were tested (Table II); all exhibited a profound inhibitory

\section{TABLE II}

SULPHONAMIDES TESTED

Sulphadiazine
Sulphacetamide
Sulphadimidine
Sulphafurazole (Gantrisin)
Sulphamethoxypyridazine (Midicel, Lederkyn)
Sulphamethoxydiazine (Bayrena, Kirocid)
Sulphadimethoxine (Madribon)
Sulphamethizole (Urolucosil, Thiosulfil)

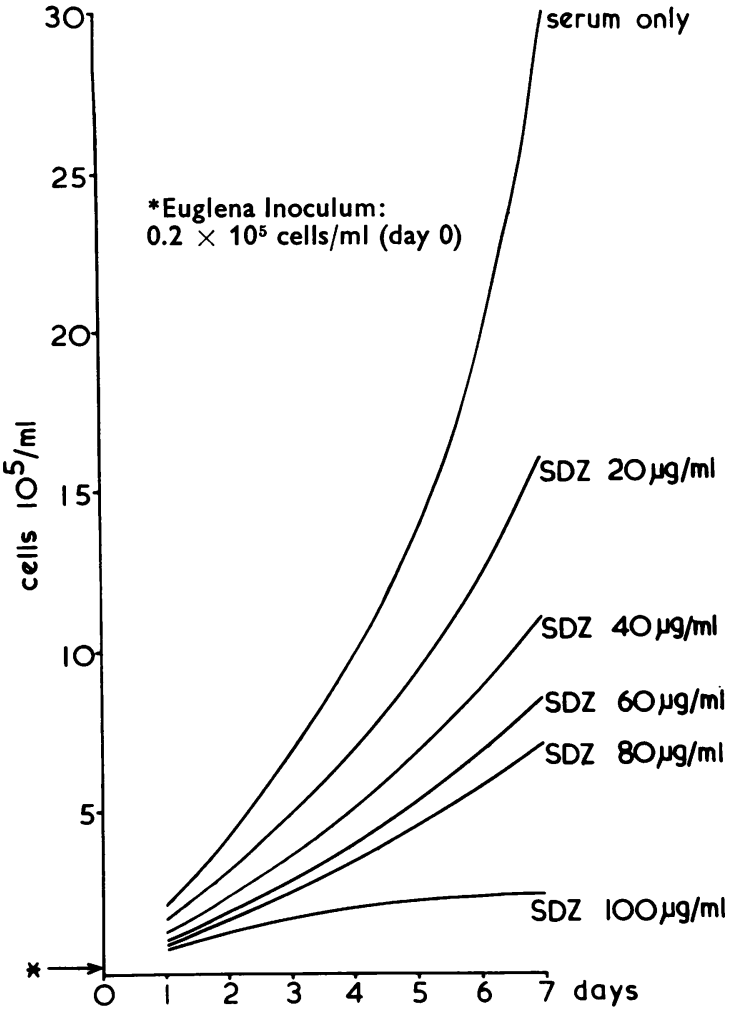

FIG. 1. Growth chart of Euglena gracilis in assay serum diluted 1 in 40, with sulphadiazine (SDZ) added in different concentrations.

effect on the growth of Euglena in direct proportion to the concentration of the drug added to the standard serum. The Euglena cell counts were markedly reduced, the flagellates remained green but appeared smaller and moved sluggishly; less than one-third of the population were motile. The effect of sulphadiazine was representative of that of other sulphonamides. In concentration as low as $20 \mu \mathrm{g} / \mathrm{ml}$, sulphadiazine reduced the growth of

TABLE III

EFFECT OF SULPHADIAZINE ON THE GROWTH OF EUGLENA ${ }^{1}$

\begin{tabular}{|c|c|c|c|c|c|}
\hline \multirow{2}{*}{$\begin{array}{l}\text { Sulphadiazine } \\
\text { Concentration in } \\
\text { Serum }(\mu \mathrm{g} / \mathrm{ml})\end{array}$} & \multicolumn{4}{|c|}{ Euglena Cell Counts $\left(10^{5} / \mathrm{ml}\right)^{2}$} & \multirow{2}{*}{$\begin{array}{l}\text { Mean Vitamin } B_{12} \\
(p g / m l)\end{array}$} \\
\hline & Day 1 & Day 3 & Day 5 & Day 7 & \\
\hline $\begin{array}{r}0 \\
20 \\
40 \\
60 \\
80 \\
100\end{array}$ & $\begin{array}{l}2.1 \\
1.6 \\
1.2 \\
1 \\
0.8 \\
0.7\end{array}$ & $\begin{array}{l}6 \cdot 8 \\
4 \cdot 8 \\
3 \cdot 6 \\
2 \cdot 8 \\
2 \cdot 5 \\
1 \cdot 6\end{array}$ & $\begin{array}{r}13.5 \\
9.2 \\
6.8 \\
5.2 \\
4.5 \\
2.2\end{array}$ & $\begin{array}{l}30 \\
16 \\
11 \\
8 \cdot 5 \\
7 \\
2 \cdot 5\end{array}$ & $\begin{array}{r}550 \\
180 \\
32 \\
16 \\
8 \\
4\end{array}$ \\
\hline
\end{tabular}

${ }^{1}$ Dilution of assay serum : 1 in $\mathbf{4 0}$

${ }^{2}$ Size of Euglena inoculum (day 0 ) : $0.2 \times 10^{5} \mathrm{cells} / \mathrm{ml}$. 


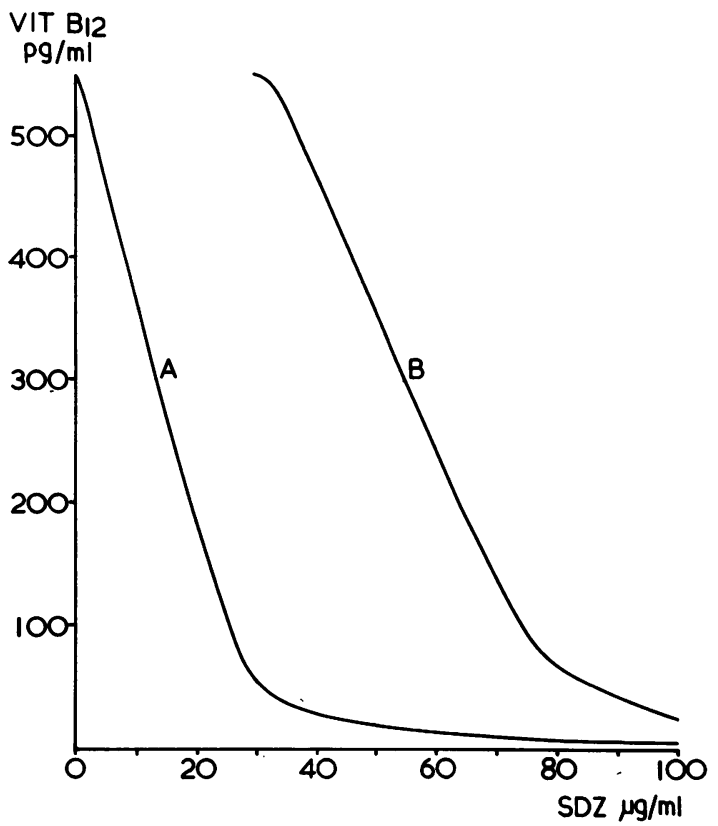

FIG. 2. The effect of sulphadiazine (SDZ) added to the assay serum in different concentrations on the results of serum vitamin $B_{12}$ assay. $A=$ assay serum diluted 1 in 40 ; $\mathrm{B}=$ assay serum diluted 1 in 80.

Euglena as measured by the cell counts to approximately one-half of that in the drug-free serum; with $100 \mu \mathrm{g} / \mathrm{ml}$, the growth was negligible (Table III and Fig. 1). The inhibitory effect of sulphadiazine was more marked in serum diluted 1 in $\mathbf{4 0}$ than in serum diluted 1 in 80 (Fig. 2), but could be abolished by simultaneously adding $1.25 \mu \mathrm{g} / \mathrm{ml}$ of para-aminobenzoic acid to the serum before assay. Para-aminobenzoic acid alone did not enhance or suppress the growth of Euglena.
THE EFFECT OF ANTIMICROBIAL AGENTS IN CONCEN은 TRATIONS EXCEEDING THE NORMAL PEAK THERAPEUTIC BLOOD LEVELS The results are summarized in Table? IV. In concentrations exceeding 10 times the norma? peak therapeutic blood levels, benzylpenicillin $\frac{\overline{\bar{n}}}{\bar{\pi}}$ chloramphenicol, ampicillin, cephaloridine, methicillin, colistimethate, and gentamicin had noo significant effect on the growth of Euglena. Streptow mycin, erythromycin, chlortetracycline, and kana $\overrightarrow{0}$ mycin affected the growth of Euglena resulting insignificantly lower colorimetric measurements of serum vitamin $\mathbf{B}_{12}$ levels. Microscopy of assay cul tures and Euglena cell counts showed that the low results were due to the bleaching effect of the drug\$ and not to inhibition of cell multiplication. Nitroer furantoin was unique in that it not only bleachedr Euglena but also suppressed the multiplication of the cells.

\section{DISCUSSION}

The presence of certain antimicrobial agents in the serum affects the growth of Euglena gracilis by sup@ pression of cell multiplication, inhibition of chloro phyll formation, or both, resulting in false low results of serum vitamin $B_{12}$ assay.

Both short- and long-acting sulphonamides sup press the multiplication of Euglena without bleaching the flagellates even when the concentration of the drug in serum is only a fraction of the normal pealo therapeutic blood levels (Tables I and III). The selection of serum diluted 1 in 80 for assay ast suggested by Anderson (1964) reduced the inhibitory effect of sulphonamides but only slightly (Fig. 2) The inhibitory effect of sulphonamides can be overe. come by the addition of para-aminobenzoic acid to the serum before assay in a concentration of $1 \cdot 29$ $\mu \mathrm{g} / \mathrm{ml}$. Since para-aminobenzoic acid alone does no

TABLE IV

EFFECT OF ANTIMICROBIAL AGENTS IN CONCENTRATIONS 10 TIMES THE NORMAL PEAK THERAPEUTIC BLOOD LEVELS ON THE EUGLENA METHOD OF SERUM VITAMIN $B_{12}$ ASSAY

\begin{tabular}{|c|c|c|c|c|}
\hline Drug Added to Serum & $\begin{array}{l}\text { Concentration } \\
(\mu g / m l)\end{array}$ & $\begin{array}{l}\text { Mean Cell Count on } \\
\text { Day } 7\left(10^{5} / m l\right)^{2}\end{array}$ & Colour of Euglena & $\begin{array}{l}\text { Mean Vitamin } B_{12} \\
(p g / m l)\end{array}$ \\
\hline $\begin{array}{l}\text { None } \\
\text { Benzylpenicillin } \\
\text { Streptomycin } \\
\text { Chlortetracycline } \\
\text { Erythromycin } \\
\text { Chloramphenicol } \\
\text { Methicillin } \\
\text { Ampicillin } \\
\text { Cephaloridine } \\
\text { Colistimethate } \\
\text { Kanamycin } \\
\text { Gentamicin } \\
\text { Nitrofurantoin }\end{array}$ & $\begin{array}{l}0 \\
100 \text { (unit/ml) } \\
500 \\
250 \\
500 \\
500 \\
250 \\
20 \\
250 \\
50 \\
250 \\
20 \\
20\end{array}$ & $\begin{array}{l}30 \\
29 \\
27 \\
28 \\
28 \\
29 \\
31 \\
30 \\
31 \\
29 \\
27 \\
29 \\
22\end{array}$ & $\begin{array}{l}\text { Green } \\
\text { Green } \\
\text { White } \\
\text { White } \\
\text { White } \\
\text { Green } \\
\text { Green } \\
\text { Green } \\
\text { Green } \\
\text { Green } \\
\text { White } \\
\text { Green } \\
60 \% \text { Green } \\
40 \% \text { White }\end{array}$ & $\begin{array}{l}550 \\
496 \\
116 \\
194 \\
208 \\
496 \\
504 \\
562 \\
530 \\
518 \\
188 \\
482 \\
176 \\
176\end{array}$ \\
\hline
\end{tabular}


enhance or suppress the growth of Euglena, and sulphonamides are among the most frequently used antimicrobial agents, the addition of para-aminobenzoic acid should be a routine step in the Euglena method of serum vitamin $\mathbf{B}_{12}$ assay. This was recommended by Hutner et al (1956) and accepted by Anderson (1964) but has not been universally adopted. Because neither pteroylglutamic acid nor citrovorum factor corrected the inhibitory effect of sulphonamides on the growth of Euglena, Lear et al (1954) suggested that para-aminobenzoic acid was concerned with nucleic acid and/or aminoacid synthesis rather than folic acid synthesis.

We have also confirmed that streptomycin, chlortetracycline, erythromycin, and kanamycin inhibit the formation of chlorophyll in Euglena without suppressing cell multiplication-'apochlorosis' (Robbins et al, 1953; Zahalsky et al, 1962)and that nitrofurantoin not only bleaches Euglena but also suppresses their multiplication (McCalla, 1962). The effect of these drugs is apparent only in concentrations exceeding 10 times the normal peak therapeutic blood levels (Tables I and IV). The serum vitamin $B_{12}$ assay is likely to be affected only when these drugs are administered in exceptionally high doses or when severe renal and/or hepatic failure delays their clearance from the blood. The inability of Euglena to form chloroplasts may be due to interference with the replication of DNA-con- taining cytoplasmic entities which are responsible for plastid formation (Smillie, 1963).

From a clinical point of view, it is essential to be sure that a low result of serum vitamin $B_{12}$ assay is actually due to low serum vitamin $B_{12}$ level. Microscopy of assay cultures and Euglena cell counts are simple methods of detecting false low results of serum vitamin $B_{12}$ assay due to the presence of inhibitory and/or bleaching substance in the serum.

We are grateful to Mr Neil Naismith, Chief Pharmacist of the Royal Melbourne Hospital, and his staff, for their help in preparing the antimicrobial agents used in this investigation.

\section{REFERENCES}

Anderson, B. B. (1964). J. clin. Path., 17, 14.

Carroll, G., Brennan, R. V., and Jacques, R. (1955). Sth. med. J. (Bgham, Ala.), 48, 149.

Goodman, L. S., and Gilman, A. (1965). The Pharmacological Basis of Therapeutics, 3rd ed., pp. 1153, 1203, 1210, 1213, 1234, $1247,1261,1266,1271,1277,1281$, and 1291. Macmillan, New York.

Hutner, S. H., Bach, M. K., and Ross, G. I. M. (1956). J. Protozool., 3, 101 .

Lear, A. E., Harris, J. W., Castle, W. B., and Fleming, E. M. (1954). J. Lab. clin. Med., 44, 715.

McCalla, D. R. (1962). Science, 137, 225.

Robbins, W. J., Hervey, A., and Stebbins, M. E. (1953). Ann. N.Y. Acad. Sci., 56, 818.

Smillie, R. M. (1963). Canad. J. Bot., 41, 123.

Zahalsky, A. C., Hutner, S. H., Keane, M., and Burger, R. M. (1962). Arch. Mikrobiol., 42, 46. 